\title{
How Oil Contracts Affect Human Rights
}

\author{
Maria João Mimoso \\ Associate Professor \\ Researcher Portucalense Institute for Legal Research \\ Clara da Conceição de Sousa Alves \\ Portucalense University \\ Diogo Filipe Dias Gonçalves \\ Portucalense University \\ Pedro Miguel Ferreirinha Pinto Alves
}

Portucalense University

\begin{abstract}
Since the beginning of the $19^{\text {th }}$ century, we have assisted major proliferation of the oil and gas industry. This phenomenon of exponential growth is due to the fact that oil companies hold the world's oil monopoly on the extraction, processing and commercialization. Therefore, as being one of the most influential sectors in the world, is crucial to strictly regulate how oil and gas contracts concerns the potential environmental and social impacts arising from the conduct of petroleum operations and how such behavior affects the human rights. As a matter of fact, the social issues field is an emerging area, and despite such importance, oil contracts do not often deal with them in great detail, corresponding to an actual emptiness of the human rights provisions. In terms of responsibly, oil companies, have an inalienable obligation to ensure that their actions do not violate human rights or contribute for their violation. This study aims to trace a detailed analysis of the impact of the oil and gas agreements in human rights. In order to fully comprehend the deep effects of this industry, we will examine, in detail, numerous of published oil and gas agreements, as well as, decode which are the real standards and practices accepted by this industry. We will use a deductive and speculative reasoning. We will try to demonstrate how incipient and short protection is given to human rights and what responsible conducts must urgently be developed.
\end{abstract}

Keywords: Oil Agreement, Human Rights, Oil and Gas Sector;

\section{Introduction}

Human rights are basic standards aimed at securing dignity or equality for all and every human being is entitled to enjoy them without any discrimination.

Once, oil and gas contracts often do not deal with potential environmental and social impacts arising from the conduct of petroleum operations, resulting in a true absence of such clauses, what we pretend, with this paper is to analyse the impact of the oil and gas agreements in human rights.

Nevertheless, international human rights law developed in order to protect individuals from oppressive and abusive actions of the state.

However, several states do not live up to his obligations. Third World countries see constantly their human rights violated through the operations of foreign corporations within their domain. They do not have the economic and political will, to bring companies under control, because the systemic corruption is often associated with them. 
The companies operating in the oil sector and the gas must comply with the law and seek to minimize the impacts of their activities on local communities of the rich natural resources and territories wishing to explore.

As a result, there is still a long way to fully protect human rights and to hold this censurable conducts, measures do not depend on the States itselfs but on ordinary society too.

There is an urgent need to appeal and to raise awareness of the importance of human rights and how they are being violated, although the major part sees the oil companies as a development of economy and not as a destructive and limiting of this rights.

\section{Chapter 1: The Dimension of Human Rights}

"Human rights - civil, political, economic, social and cultural rights -- must never be seen as a luxury or "saved for later", after peace and development have been achieved. Human rights are an intrinsic part of all that we do - and all that we are. And so we must speak up for human rights in an impartial way without double standards.

We must invest in human rights and recognize human rights as values and goals unto themselves - not allowing them to be instrumentalized as a political tool." António Guterres, Secretary-General of the United Nations, speech at Human Rights Council (fev. 2017).

Human rights, as we know them today, have not always existed. Since the end of the Second World War, and the creation of the United Nations, the international community vowed never again to abide the unspeakable atrocities the world had just witnessed. So the leaders of the world decided to amplify and encouraging the guarantees for the rights of human beings everywhere (Gordon, 2016).

The Universal Declaration of Human Rights (UDHR), proclaimed by UN General Assembly in 1948, stated a new era of law by recognising the equal and the inalienable rights of humankind, in which, hope, freedom, justice and peace set foundations for a better world. The UDHR established an international standard and codification of human rights norms and was signed for 148 countries (Bekefi, 2004).

The Inter-Parliamentary Union \& United Nations (2016), define human rights as relationships between individuals and power structures, especially the State. Human rights delimit State power and, at the same time, require States to take positive measures ensuring an environment that enables all people to enjoy their human rights.

The UDHR is matched in many cases by the rights provisions of national constitutions, charters, and bills of rights (Gordon, 2016). In this way, the UDHR clearly inspired national legislators to safeguard human rights in the new constitutions of the world's youngest countries, which were in this context an example to follow.

The UN has also developed other protocols, based on the UDHR, to address specific human rights principles. The International Covenant on Economic, Cultural and Social Rights, and the International Covenant on Civil and Political Rights, combined with the Core Labour Standards of the International Labour Organisation serve as the basis for human rights in the legal, political, and social spheres (Bekefi, 2004).

The UDHR was originally formulated as "soft law", not legally binding (Gordon, 2016). Soft law is a type of social rather than legal norm. We can define "soft law" as referring to any written international instrument, other than a treaty, containing principles, norms, standards, or other statements of expected behavior (Shelton, 2008).

In Articles 22 to 26 of the UDHR, we have defined social and economic rights, which include provisions relating to social security, conditions of work, rest and leisure, standard of living, and education. At this point, we need to distinguish two dimensions of fundamental rights. The first dimension imposes an abstention of the action of the State against the individual rights of the human being because they are civil and political rights. It is a space of self-determination of the individual in relation to the performance of the state. The right to liberty, life, physical integrity and property are examples of this first category of rights. On the other hand, second-level rights require direct action by the state to take effect. We are facing social, cultural and economic rights (Ferraresi, 2012).

For obvious reasons, the international community is more aware of social, cultural and economic issues today than it was in 1948. Despite of the international community has not recognized a human right to a decent and liveable environment, we believe that we should embrace the right to a safe, clean, healthy, and sustainable environment, with a right of access 
for everyone to such elementary resources as clean air, clean water, and clean, safe, and sustainable energy. Social and economic rights are vital. They reflect genuine human needs that every state has an obligation to attend to, within existing resources, in the interest of all those committed to their care. This rights are conceptually linked to civil and political rights because respect for human dignity requires that both be upheld. Indeed, the failure of social and economic rights makes individuals more vulnerable to other human rights abuses, such as forced labor (Gordon, 2016).

In terms of responsibility, it is right for the world to indicate to governments that attention to matters of social security, conditions of work, rest and leisure, standard of living, health, and education are now regarded as elementary and fundamental tasks of government, laid down as compelling priorities in relation to whatever resources are available. The rights here are not optional and they are not just wistful longings. A lack of resources does not turn such rights into a mere wish list. Countries have a categorical obligation to do all that they reasonably can to fulfil these rights (Gordon, 2016).

It is important not to forget what the preamble of the UDHR says that "every individual and every organ of society, keeping this Declaration constantly in mind, shall strive by teaching and education to promote respect for these rights and freedoms and by progressive measures, national and international, to secure their universal and effective recognition and observance".

The rights must be absorbed into the legal, administrative and political culture of nations, first by a recognition that they are achievable ideals and then by implementation in national law and administration through relevant political and social reforms (Eide, 2000).

States must, at the primary level, respect the resources owned by the individual, his or her freedom to find a job and the freedom to take the necessary actions and use the necessary resource to satisfy his or her own needs. It is in regard to the latter that collective or group rights become important: the resources belonging to a collectivity of persons, such as indigenous populations, must be respected in order for them to be able to satisfy their needs. Consequently, as part of the -obligation to respect these resources, the state should take steps to recognize and register the land rights of indigenous peoples and land tenure of smallholders whose title is uncertain. Similarly, the rights of peoples to exercise permanent sovereignty over their natural resources may be essential for them to be able, through their own collective efforts, to satisfy the needs of the members of that group (Eide, 2000).

At a secondary level, state obligations mean to protect the freedom of action and the use of resources against other, more assertive or aggressive subjects -more powerful economic interests, such as protection against fraud, against unethical behaviour in trade and contractual relations, against the marketing and dumping of hazardous or dangerous products (Eide, 2000).

So far, all existing legislation has been based on protecting human rights from abuses and oppression by the state. Nowadays, with the help of globalization, new entities have emerged that challenge human rights, such as transnational oil and gas companies.

The oil and gas sector is one of the most influential markets in the world. Legislation has been needed to ensure that these transnational corporations do not put pressure on human rights.

\section{Chapter 2: The Applicable Law of the oil contracts (Lex Petrolea)}

Commercials relationships have been, for a long time, regulated by international trade practices which have been developed and settled over the years. Therefore, these have achieved a status of international normative body, commonly designated, since the Middle Ages, by Lex Mercatoria.

Although some considerable controversy has arisen over the years, regarding the nature and delimitation of this anacional normative set of rules, it seems to us that it includes general principles of law, uses of international trade, as well as contractual practices by sector of market (Baptista, 2010).

Each sector of international trade has contributed effectively to its elaboration, and as it evolves, Lex Mercatoria has been including several different realities.

The concepts of legal security and legal certainty will not be foreign or remote to the development of International Trade. 
Since its early days, it became apparent that one of the obstacles lay in the plurality of national legal systems which could govern the same legal relationship because of the contact points with it.

Several entities in the world have contributed to the construction and acceptance of the so-called New Lex Mercatoria. We speak above all of the Chamber of International Trade in Paris, the United Nations Commission for International Trade Law, the UNIDROIT Institute and the contribution of certain sectoral associations dedicated to the standardization of contractual behavior, thereby implementing legal certainty in the relations of the sector in which they operate.

It should be noted that the creation of contractual models based on the customs and practices within international trade is currently unquestionable. Certain contractual species claim models because of their peculiarity and complexity, and the parties can, in accordance to the circumstances of each particular case, adaptable to them. They are seen as expeditious elements of the legal relationships that are established, capable of implementing legal security and greater certainty in international commercial relations.

The internationalization of the oil industry occurred at a time when certain companies began exporting oil from producing countries to non-producing countries, although these were considered as real economic powers. All conditions were therefore created for the existence of a genuine international oil market.

In this sector, commercial relations imply the existence of several national and international protagonists, namely multinational companies (International Oil Companies - IOC), Host Oil Countries (HOC) and National Oil Companies (NOC).

We can not forget that in oil and gas contracts we have opposite interests. On the one hand, the interests of the State over its natural resources and the need to manage these contracts while safeguarding the contractual public interest; on the other, the individual interests, who claim protection in continuity and contractual stability.

These relations therefore carry high risks. The State may at any time introduce changes, whether contractual or legislative, impairing contractual stability, e.g. expropriations and nationalizations and changes in fiscal policies. Consequently, normative specialization has become inevitable for this type of relationship.

Thereby, a need arises to create, in the context of the international oil trades and because of the high importance of the oil and gas industry, material rules to govern such relations. We talk about a Lex Mercatoria specialization, commonly known as Lex Petrolea.

This expression arose for the first time in the ARAMCO v. Saudi Arabia (1958), submitted to an arbitral tribunal and concluded that there is a valid and effective "customary" law for the oil industry (Martin, 2012).

This regulation early went beyond arbitration, and become a true discipline of international trade relations in the oil sector, encompassing contractual models that facilitate relations between the parties.

These contracts intended to standardize terms commonly used in the petroleum industry that are internationally recognized. We refer to the concession agreement, the sharing agreements, the participation agreement, among others.

Lex Petrolea is used by the courts, and it is in the context of arbitration that the contractual models are analysed and tested, evidencing their characteristics and the need to adapt them to reality.

Lex Petrolea will apply to the international contracts of the sector whenever they refer to it or whenever they allude to the general principles of law and the good practices of the petroleum industry.

Although international arbitration is not tied to the precedent rule, we noted that arbitral justice actors, arbitrators and lawyers, commonly use precedent decisions to justify, substantiate decisions and to outline his points of views respectively.

The construction of Lex Petrolea's main scope is to discipline international trade relations in the oil industry (Van den Berg, 1994).

Although certain arbitration conventions also provide for the application of a given national law to resolve disputes arising out of an oil contract, the principles of Lex Petrolea must always be considered.

In ARAMCO v. Saudi Arabia, the arbitral court held that the applicable national law should be interpreted and supplemented in accordance with the general principles of law, customs and good practices of the oil industry. 
In 1963, the Sapphire International Petroleum v. NIOC case, the arbitrators substantiated the application of Lex Petrolea on the basis of the principle of good faith and cooperation between the parties, diverting the national law from the receiving State.

In the case of British Petroleum (BP) v. Libya in 1973, the arbitrators applied subsidiary Lex Petrolea to fill gaps in Libyan Law (Favacho, 2011).

In 1982, in another case, Kwait v. AMINOIL, the government concerned based its claim on a set of arbitration decisions handed down in disputes arising out of oil contracts.

Since Lex Petrolea is disconnected from any state legal system, and therefore not suffering the influences and prerogatives of the states, early on contributed to overcoming problems in the regulation of oil contracts.

Lex Petrolea, not bound by any legal system in particular, was able to sediment the internationally accepted practices. This has contributed to its success, since its acceptance is undeniable both by the host States and by transnational corporations.

We can therefore consider Lex Petrolea as a spontaneous disciplinary order created by the protagonists of the international oil industry in order to provide for the antagonistic and often conflicting interests of the protagonists it is undoubtedly in the equidistance of national rights that it establishes its autonomy, independence and legitimation (Jesus, 2012).

\section{Chapter 3: When things go wrong}

\section{Corporate Social Responsibility in Oil and Gas Industry}

As stated earlier, oil and gas are the largest source of energy for our modern world, and this industry is largely shaped by the supply and demand conditions.

In the beginning, developing countries did not have the infrastructure for refining crude, neither his markets for absorbing the refined products, and therefore, this resulted in a supply that far exceeded the demand. Developing countries exported crude to the larger developed countries markets, where processing took place and the final products were sold.

The contractual terms mainly focused on fiscal terms and financial gains, which reflected this preference for obtaining revenues from royalties and taxes rather than production sharing (Boykett, Peirano, Boria, Kelley, Schimana, Dekrout, OReilly, 2012).

By analysing oil agreements and their history, we see that there is a recent concern of many developing oil producing states about the social and economical issues, since they started to realise that the petroleum sector can contribute much more to their welfare and overall development than solely through revenues.

Illustrating with an exemple, we quote the preamble of the 2012 Kurdistan Regional Government Production Sharing Contract, which says: "The Government wishes to develop the petroleum wealth of the Kurdistan Region (as defined in this Contract) in a way that achieves the highest benefit to the people of the Kurdistan Region and all of Iraq, using the most advanced techniques of market principles and encouraging investment, consistent with the Constitution of Iraq including, without limitation;"

Also, this contractor must be "willing to cooperate with the Government by entering into this Contract, thereby assisting the Government to develop the Kurdistan Region petroleum industry, thereby promoting the economic development of the Kurdistan Region and Iraq and the social welfare of its people".

Regarding this specific agreement, by the introduction of such clauses, we can conclude that whatever path lies ahead for the Kurdish energy sector, the sustainability of Iraqi Kurdistan development seems to be necessarily linked to a twofold diversification: diversification of the productive structure of the regional economy, essential to avoiding the social, political and economic risks related to over-dependency on oil revenues, on the one hand, and diversification of energy export channels, unavoidable in order to limit the degree of political vulnerability to transit countries (Frappi, 2016).

Although, the preoccupation with corporate ethics and the social dimensions to business activity is not new, the focus on international development, or rather the private sector contribution to international development goals, is a relatively recent phenomenon (Frynas, 2008). 
This new idea that a company should be interested in and willing to help society and the environment as well as be concerned about the products and profits it makes, is the base and definition of Corporate Social Responsibility or CSR.

\section{CSR and Development}

In fifty years, CSR has evolved from social movements regarding civil rights, women's rights, consumers, environmentalism, to corporate responsibility and responsiveness, and more recently to a corporate social performance which includes business ethics, corporate citizenship, sustainability and stakeholder management (Carrol, 2015).

Nowadays, oil and gas companies can use their influence in the world to develop regions in the surrounding areas points of extraction. This industry now helps to build schools and hospitals, launch micro-credit schemes for local people and assist youth employment programs, particularly in developing countries.

Some authors, have proposed to think of CSR as an umbrella term for a variety of theories and practices that each recognize that companies have a responsibility for their impact on society and the natural environment, sometimes beyond that of legal compliance and the liability of individuals; that companies have a responsibility for the behaviour of others with whom they do business (within supply chains); and that business needs to manage its relationship with wider society, be that for reasons of commercial viability or to add value to society (Frynas, 2009).

In a broader context, the calls for greater involvement of private firms in human development reflect the growing importance of foreign direct investment relative to official development assistance to developing countries, despites the unlikely to play the significant role in poverty reduction in development countries that its proponents claim for (Jenkins, 2005).

As a consequence of liberalization and deregulation, oil companies are now being called upon to go beyond their traditional role of generating economic growth toward playing a more direct role in alleviating poverty and other development goals (Frynas, 2008).

CRS concerns are determined by the nature of an industry and the State or culture where that industry operates. For instantes, in the oil and gas industry, even though operations occur in many countries, the key concerns such as the macroeconomic difficulties related to oil revenues, the environment and the social impact on local communities, are shared between most countries.

Dealing with dangerous operations with highly negative effects, oil corporations are permanently under great pressure to manage their relationship with society.

Events, widely reported by the media, such as oil spills, the protests anti-oil, campaigns to save the environment and indigenous people from oil operations, the involvement of oil industry in human rights abuse in Colombia or Nigeria's corruption and economic problems caused by oil companies, pressure companies to rethink about future strategies and the circumstances of corporate social responsibility.

For instance, in the oil and gas sector, companies such as Total, Shell and Exxon each spend well over US\$100 million on community investments every year (Frynas, 2009). Hence the major importance of such matters.

However, there are many reports of social investment that went heavily wrong, either by bad administration and poor project management, or by lacking of basic equipment, or by being unsuitable dysfunctional for the community.

As an extreme example, a company built a fish processing plant in a local community, which was a long way from the trade markets, as a result of insufficient local consultation.

Or the case of a company that built three town halls in one African local community in order to maintain a stable working environment in the process of building a pipeline, because the company followed the short-term interests of three community chiefs who wanted to benefit personally from construction contracts (Frynas, 2009).

Oil companies are also accused of the lack of transparency and of interfering in governance, influencing States elections by corrupting candidates in order to gain advantages.

We can conclude that, despite the CSR importance, due to the great influence of this industry, today it can be argued that it can be more detrimental to oil-producing countries than the environmental impact of oil operations themselves and that 
the alleged corporate social responsibility efforts do not outweigh and can not offset the atrocious human rights violations along the way.

\section{Chapter 4: Responsibility of Human Rights Violations}

Capitalism, globalisation and neo-liberalism have paved the way for the emergence on the international scene of economic colossuses with quasi-legal personality (Malanczuk, 1997)).

These modern leviathans wield considerable social and political influence over countries, in addition to their overwhelming economic leverage (Miller, 1995).

See that Shell Oil's 1990 gross national income was more than the combined GNPs of Tanzania, Ethiopia, Nepal, Bangladesh, Zaire, Uganda, Nigeria, Kenya and Pakistan - countries that represent almost one-tenth of the World's population

Transnation Corporations (TNCs), through foreign direct investment in developed and developing countries, create jobs, improve technology and inject capital. But they equally have a negative impact on the areas where they operate, particularly in poor Third World or developing countries. Frequently, their activities result in human rights violations. The abused human rights are more often than not those that fall within the international definition of economic, social and cultural rights (Kamminga, 1999).

Since the last two decades, however, the emphasis has been on the adoption of corporate social responsibility initiatives, international and national in origin, to effectively address concerns regarding human rights violations by TNCs.

The bottom line is that there is no single international regime of human rights law directly applicable to, and governing, transnational operations of corporations.

Customary international human rights law developed in order to protect individuals from oppressive and abusive actions of the state. Perhaps a failure to recognise or contemplate $a b$ initio that powerful non-state actors such as TNCs could violate human rights may be attributed to the fact that only states were players in the international arena (Cutler, 2001).

However, international law leaves states with the obligation to control and restrain within their territories the activities of non-state actors that violate human right (McCorquodale, Simons, 2007).

It is not in doubt that several states do not have what it takes to live up to this obligation. Weak Third World countries that see these human rights violations through the extra-territorial activities of foreign corporations within their domain, do not have the economic and political will to bring TNCs under control. The situation is further exacerbated by the systemic corruption often associated with Third World countries (Khan, 2009).

At one time it was thought that where a host state is unwilling or incapable of reacting appropriately to human rights abuses, the home state of the corporation may have a crucial role to play ensuring that corporate abuses do not go unpunished, and some home states have attempted to use extra-territorial legislation to achieve this end (Ruggie, 2008).

Several states tried to implement measures, for example the uk suggested creating a specific figure for violation of these human rights. However, this did not translate into legislation.

Criminal prosecution is the highest level of state reprimand against an offending entity. Consequently, the joint venture alliance (and sometimes production-sharing contracts) between the state (represented by NNPC) and the oil TNCs raises the question as well as suggesting why the state has not mustered the courage to apply the strictest level of sanctions against entities in which it has vested an economic interest.

It may be recalled that it is in part the failure of states to rise above political and economic considerations and visit justice on atrocities committed within their territories that necessitated the creation of the International Criminal Court (ICC), not that the states do not have appropriate criminal regimes for the designated offences. A fortiori, the necessity of subjecting TNCs to the jurisdiction of the ICC is canvassed not because host states do not have appropriate corporate criminal regimes, but because the use of such domestic criminal regimes to secure justice for victims of these crimes is seemingly undermined by factors that relate to political and economic considerations, as well as corruption.

The ICC is a permanent tribunal established to prosecute individuals for genocide, crimes against humanity and war crimes. 
Essentially, the ICC complements existing national judicial systems and only exercises its jurisdiction where a national jurisdiction is unwilling or unable to investigate or prosecute designated crimes. This is the idea encapsulated in the ICC's complementarity principle (Zeidy, 2008).

The negative impact of their activities manifests itself in wide-scale and grave abuses of human rights. The hapless citizens bear the worst of these human rights abuses. Despite their enormous economic activity and the amount of literature that has been produced on them, there is still no single legal instrument that regulates their activities meaningfully.

The fundamental reason for considering that the ICC is appropriately positioned to act also as a criminal court for TNCs is that the ICC is an uninterested third party (unassociated with neither the host nor home state) to whom grievances of human rights violations can be lodged by victims. It would thus be in a position to act without being influenced by any form of economic considerations that often dominate the decisions of the current state officials to check the atrocious activities of the TNCs (Haigh, 2008).

A challenge to extending the ICC's jurisdiction to TNCs, however, is the issue of the non-recognition of corporate criminal liability by some state parties to the treaty, also the reason behind the failure at the Rome Conference to extend the ICC's jurisdiction over corporations.

the complementarity principle in the Rome Statute would not be threatened by a proposal to extend the ICC's jurisdiction to corporations. The arguments canvassed as the basis for opposing the extension of the jurisdiction of ICC to TNCs, are untenable. Indeed, complementarity concerns were merely used as a cover for states' anxiety about how competing tension between state sovereignty and the international criminal justice would be resolved if the ICC's jurisdiction stretched to TNCs (Kyriakakis, 2008).

To see that a number of UN conventions have already recognised corporate criminality at the international level.

In conclusion, a critical mind may want to ask why Third World countries, have not of their own accord employed a corporate criminal regime to effectively punish or stop TNCs from human rights violations without seeking the assistance of the ICC. The truth is that, like some Western common law jurisdictions that have corporate criminal regimes, this countries, for instance, recognises this concept but has not effectively put it to use as machinery for seeking justice against corporations.

\section{Conclusions}

1. States shall respect, protect and guarantee human rights and fundamental freedoms, as well as punish corporate conduct;

2. The companies operating in the oil sector and the gas must comply with the law and seek to minimize the impacts of their activities on local communities of the rich natural resources and territories wishing to explore;

3. The beneficiaries of this sector, host States and companies, must increasingly implement protective measures of the most basic fundamental rights, assuming social and corporate responsibility;

4 Thus, there must be an awareness of the appropriateness of the behavior of companies in the face of local populations;

5. International organizations are becoming more aware of this reality, acting incisively, seeking thereby influence behavior and changing mentalities;

6 The assumption of social responsibility is currently a form of ethical and integrated management, contributing not only to business success but also to the promotion of human rights;

7. Transparent and assertive behaviors by all the protagonists of this sector will eventually contribute to the sustainable development of our planet.

\section{References}

[1] Baptista, L. O. (2010). Contratos Internacionais. São Paulo: Lex Editora.

[2] Bekefi, T. (2004). Human rights policy implementation in the oil and gas sector: translating policy to practice. Retrieved from: https://www.commdev.org/userfiles/files/1695_file_HRimplementation_final.pdf 
[3] Boykett, T., Peirano, M., Boria, S., Kelley, H., Schimana, H., Dekrout, A., OReilly, R. (2012). Oil Contracts: How to Read and Understand a Petroleum Contract. (pp: 125-143) Austria: Open Oil

[4] Carroll, A. B. (2015). Corporate social responsibility: the centerpiece of competing and complementary frameworks. Organizational Dynamics, 44 (2), 87-96. Retrieved from: https://www.researchgate.net/publication/273399199_Corporate_Social_Responsibility

[5] Cutler, A. (2001). Critical reflections on the Westphalian assumptions of international law and organization: A crisis of legitimacy. Review of International Studies.

[6] Eide, A. (2000) Economic and Social Rights. Retrieved from: http://www.corteidh.or.cr/tablas/r28245.pdf

[7] Favacho, F. (2011). A gestão de conflitos em contratos internacionais do petróleo. Revista Brasileira de Direito Constitucional - RBDC n. 18 - jul./dez. Disponivel em: http://www.esdc.com.br/RBDC/RBDC18/RBDC-18-243

Artigo_Frederico_Favacho_(A_Gestao_de_Conflitos_em_Contratos_Internacionais_do_Petroleo).pdf

[8] Ferraresi, C.S. (2012). Direitos fundamentais e suas gerações. Revista JurisFIB, 3, 321-336.

[9] Frappi, C. (2016). Oil and State building in Iraqi Kurdistan. Retrieved from: https://www.researchgate.net/publication/308777708_Oil_and_State_building_in_Iraqi_Kurdistan

[10] Frynas, G. (2009). Corporate social responsibility in the oil and gas sector. The Journal of World Energy Law \& Business, 2 (3), 178-195. Retrieved from:

https://www.researchgate.net/publication/247577729_Corporate_social_responsibility_in_the_oil_and_gas_se ctor

[11] Frynas, J. G. (2008). Corporate Social Responsibility and International Development: Critical Assessment. Csr and International Development, 16 (4), 274-281. Retrieved from: https://onlinelibrary.wiley.com/doi/abs/10.1111/j.1467-8683.2008.00691.x

[12] Gordon, B. (2016). The Universal Declaration of Human Rights in the 21st Century: A Living Document in a Changing World. Cambridge, UK: Open Book Publishers. doi: 10.11647/OBP.0091

[13] Haigh, K (2008). Extending the International Criminal Court's jurisdiction to corporations: Overcoming complementarity concerns

[14] Inter-Parliamentary Union \& United Nations. (2016). What are human rights? In Inter-Parliamentary Union \& United Nations (Ed.), Human Rights : Handbook for Parliamentarians (pp. 19-30). Retrieved from: https://www.ohchr.org/Documents/Publications/HandbookParliamentarians.pdf

[15] Jenkins, R. (2005). Globalization, corporate social responsibility and poverty. International Affairs, 81 (3), 525540. Retrieved from: https://onlinelibrary.wiley.com/doi/epdf/10.1111/j.1468-2346.2005.00467.x

[16] Jesus A. O. (2012). The Prodigious Story of the Lex Petrolea and the Rhinoceros. Philosophical Aspects of the Transnational Legal Order of the Petroleum Society, in TPLI Series on Transnational Petroleum Law, Vol. 1, N ${ }^{\circ}$ 1.Disponivel em: http://adejesus.com/pdfs/DE\%20JESUS\%200.\%20Alfredo\%20\%20The $\% 20$ Prodigious $\% 20$ Story $\% 20$ of $\% 20$ the $\% 20$ Lex\%20Petrolea $\% 20$ and $\% 20$ the $\% 20$ Rhinoceros.pdf

[17] Kamminga, M. T. (1999). Holding multinational corporations accountable for the human rights abuses: $A$ challenge for the European Community

[18] Khan, F. (2008). Understanding the spread of systemic corruption in the Third World. American Review of Political Economy, 6 (2), 16-39.

[19] Kyriakakis, J. (2008). Corporations and the International Criminal Court: The Complementarity Objection Stripped Bare. Criminal Law Forum, 19(1), 115 - 151.

[20] Malanczuk, P. (1997). Akehurst's modern introduction to international law. ( $\left.7^{a} e d.\right)$ New York, NY. Routledge Retrieved from: https://law.famu.edu/wp-content/uploads/2015/05/1.-Modern-Introduction-to-InternationalLaw.pdf

[21] Martin, T. (2012). Lex petrolea in international law' in Ronnie King, Dispute Resolution in the Energy Sector: A Practitioner's Handbook (Globe Law and Business)

[22] McCorquodale, R. \& Simons, P. (2007). Responsibility Beyond Borders: State Responsibility for Extraterritorial Violations by Corporations of International Human Rights Law. The Modern Law Review, 70(4): 598-625. Retrieved from: https://onlinelibrary.wiley.com/doi/full/10.1111/j.1468-2230.2007.00654.x

[23] Miller, A. L. (1995). Third World in global environmental politics 
[24] Ruggie, J. (2008.) Protect, respect and remedy: A framework for business and human Rights. Innovations: Technology, Governance, Globalisation, 3(2), 189-

212 https://www.mitpressjournals.org/doi/10.1162/itgg.2008.3.2.189

[25] Shelton, D.L. (2008). Soft Law. In Handbook of International Law. The George Washington University Law School, Washington D.C. Retrieved from :

https://scholarship.law.gwu.edu/cgi/viewcontent.cgi?article=2048\&context=faculty_publications

[26] Van den Berg A. J. (1994). Yearbook Commercial Arbitration 1994 Vol. XIX Vol. XIX (Kluwer Law International).

[27] Zeidy, M. (2008). The principle of complementarity in international criminal law: Origin, development and practice 157 